\title{
Eco-innovation and International Competitiveness of Enterprises Results for European Union Member States
}

\author{
Małgorzata Stefania Lewandowska \\ Ph.D., Warsaw School of Economics, Institute of International \\ Management and Marketing, Warsaw, Poland \\ e-mail:mlewando@sgh.waw.pl
}

\begin{abstract}
Intensive global warming, declining natural resources, and pollution are the factors influencing the wider debate about what creates a "green economy." Taking the above into account, the purpose of this paper is to present an overview of the eco-innovation performance of European Union members and, at the same time, their overall level of innovativeness. The paper also provides insights into the role of eco-innovation as the driving force for the international competitiveness of enterprises from European Union countries. The results at the macro level show that there is a strong interdependence between the level of innovativeness and the level of eco-innovation implementation in the EU Member States. In turn, the micro-analysis conducted for EU enterprises shows that there is an interdependence between the introduction of eco-innovation with benefits for the end-user and the level of international competitiveness measured by the intensity of exports. Enterprises from countries with a higher overall Innovation Union Scoreboard (IUS) and Eco-Innovation Scoreboard (Eco-IS) are simultaneously characterized by a higher intensity of eco-innovation, introducing benefits for the end-user, and an intensive presence with sales on foreign markets. Enterprises from countries with low IUS and Eco-IS rankings, including the countries of Central and Eastern Europe, are characterized by a relatively low intensity of introducing eco-innovation accompanied by a relatively low export intensity.
\end{abstract}

Keywords: Eco-innovation, International competitiveness, Innovation Union Scoreboard, Eco-Innovation Scoreboard, Community Innovation Survey (CIS)

JEL: F64, O32, O44 


\section{Introduction}

Recent decades of economic growth have been accompanied by growing global environmental problems, such as global warming and the increasing scarcity of natural resources. In this context, the concept of sustainable development (SD) and eco-innovation (E-I) have become a hot issue for both the economy and business, as they are at the center of the discussion on possible ways to transition to a low carbon economy.

The essence of the debates conducted on this subject is based on the concept of eco-innovation, defined as:

"The introduction of a new or significantly improved product (product or service), process, organizational or marketing method that allows limiting the use of natural resources (including materials and raw materials, energy, water and land) and reduces the emission of harmful substances throughout the product's life cycle" (Environmental Investment Organization - EIO 2010). This indicates the extension of the concept of eco-innovation from areas related to environmental protection to any processing activity.

In the literature, the links between innovativeness, including that related to eco-innovation and international competitiveness, are widely discussed, both at the macro level (WEF 2013-2014, pp. 4-7), and in the microeconomic literature (Brusoni, Cefis \& Orsenigo 2006; Halpern 2007).

In turn, analysis of the competitive strategy on the international market of enterprises from Central and Eastern Europe, including Poland, suggests that although they still have high cost and price advantages, the role of factors related to the differentiation of the offer increases significantly (Stojcic, Hashi \& Telhaj 2011), also based on ecology-related solutions.

The purpose of this study, taking into account the definition and scope of its application, is to present a review of the issues related to eco-innovation in the EU Member States, and to examine whether and to what extent there is a connection between the introduction of eco-innovation (innovations whose effects are environmentally friendly) and the sales orientation to international markets.

Those issues lead us to two research questions, at both the macro and micro level:

1. Is there a relationship between the level of overall innovation performance, measured by the Innovation Index, and the level of innovativeness related to eco-innovation measured by the Eco-Innovation Index of European Union Member States?

2. Is there an interrelation between the intensity of introducing eco-innovation with the benefits for the end-user and international competitiveness measured by the export of enterprises from European Union Member States?

Statistical analysis of the above issues is based on data from the Innovation Union Scoreboard (IUS) 2018, the Eco-Innovation Scoreboard (Eco-IS) survey from 2013-2017, and data from the Community Innovation Survey 2010-2012, for enterprises from the European Union countries in the part concerning eco-innovation and firms' market orientation. 


\section{Defining eco-innovation}

Green, sustainable, or eco-innovation is defined as the production, application, or exploration of goods, services, production process, organizational or management structures, or methods of business that are new to the company or user. The results are the reduction of environmental impact, less pollution, or fewer negative impacts from the utilization of resources compared with corresponding alternatives (Gerlach 2003; Arundel \& Kemp 2009).

The OECD defines eco-innovation as "the implementation of new, or significantly improved, products (goods and services), processes, marketing methods, organizational structures and institutional arrangements which, with or without intent, lead to environmental improvements compared to relevant alternatives" (OECD 2009, p. 40).

Eco-innovation affects, directly or indirectly, various groups of stakeholders who expect tangible benefits. This means a holistic approach to managing eco-innovations, which seems to be much more difficult than in the case of "conventional" innovation, due to the growing public awareness of sustainable development.

The above definition reflects the principles contained in the concept of Corporate Social Responsibility (CSR) being consistent with the definition of sustainable development (SD), in which the integration of social, economic and ecological issues, with the awareness of bearing their consequences and responsibility before the current and future generations, is emphasized (Dorożyński \& Kuna-Marszałek 2016; Wysokińska \& Witkowska 2016).

Comparing the "traditional" innovation with sustainable/eco-innovation, one can notice the existence of significant differences (Yarahmadi \& Higgins 2012). First of all, eco-innovation cannot be based on an open, fluid concept because it refers to innovation, which explicitly emphasize the need to reduce emissions to the environment, regardless of whether these effects were or were not previously defined (OECD 2009).

Secondly, eco-innovation is not narrowed by the definition referring to the type of innovation - product, process, marketing, or organizational - as it causes additional changes to be made concerning social norms, cultural values, and institutional structures, regardless of which areas of the company's operations a change has been made in. The scope of eco-innovation goes beyond the conventional organizational boundaries of the company to cover a wider social environment. That is why - and this is the third difference - the total environmental impact of an eco-innovation is very difficult to assess (Horbach et al. 2013).

Scientists studying the issues of eco-innovation believe that it requires more intensive, closer cooperation in the field of R\&D than is the case with "conventional" innovation (de Marchi 2012).

Much attention is also paid to the significance of eco-innovation determinants, in particular, technological stimulators (technology push) and the pressure exerted 
by demand-factors on rationalizing the innovative activity of the company (the demand-pull factors). In the initial phase of developing a new product, factors related to technology requirements are particularly important, whereas the demand factors become important in its diffusion phase (Pavitt 1984).

It is important and worth emphasizing that eco-innovation can bring positive side effects in both phases of the life cycle, the initial phase and the diffusion phase, which further increases the need for investment. The problem of "double externality" does not encourage investing in eco-innovations and is treated as an additional key feature of eco-regulation (Kemp 2000).

Expenses related to environmental protection are often treated as an additional cost imposed on enterprises, which results in the obligation to allocate certain resources to reduce pollution and, consequently, it lowers management efficiency. Many researchers, especially Michael Porter and Claas van der Linde (Porter \& van der Linde 1995b), began to call into question such an approach. They indicate that the overlapping regulations are more demanding, although when they are properly applied, they can encourage innovation and even more than fully compensate for the incurred costs (Porter \& van der Linde 1995a).

\section{Eco-innovation and the idea of sustainable development in European Union Member States}

Europe 2020, the European Union's plan outlining the development directions of the member countries, defines three mutually-related priorities: intelligent development, sustainable development, and inclusive growth. The program envisages a definite shift of the current resource management model towards a low-emission economy (EC 2010; Wysokińska 2013, 2014).

Planned projects under the Eco-Innovation Action Plan-EcoAP, which was adopted in December 2011, should facilitate the introduction and diffusion of eco-innovation. Implementing the Action Plan should bring environmental benefits, create favorable conditions for economic development, enable the creation of new jobs, and ensure the more efficient use of resources whose supply is limited. The emphasis is on eliminating development blockades, coping with challenges, and using the possibilities of achieving environmental objectives created by technological and non-technological innovations (Lewandowska 2016).

As part of the next long-term EU budget 2021-2027, a new LIFE program for the Environment and Climate Action was adopted. It focuses on protecting the environment and mitigating climate change, and supporting a clean energy transition with increased energy efficiency and a higher share of renewables in the energy mix.

As for future challenges, the European Commission adopted a long-term strategic vision for a modern, competitive, and climate neutral economy by 2050 - A Clean Planet for all. "The strategy shows how Europe can lead the way to climate 
neutrality by investing into realistic technological solutions, empowering citizens, and aligning action in key areas such as industrial policy, finance, or research - while ensuring social fairness for a just transition" (European Commission, Press Release Database).

Since monitoring the ecological situation in the Member States is one of the key tasks of the Union, a special tool for assessing and observing eco-innovation in individual member states has been built for its implementation (Eco-Innovation Scoreboard - Eco-IS).

The indicators used in the Eco-Innovation Scoreboard to assess the eco-innovation situation are divided into five groups, including: (1) eco-innovation inputs (including expenditure related to the early stage of investment in clean technology); (2) eco-innovation activities; (3) eco-innovation results (e.g., relevant patents); (4) resource efficiency; (5) socio-economic results (such as turnover resulting from the implementation of eco-innovation, employment related to eco-innovation, and exports resulting from eco-innovation).

The indicators created to reflect the turnover and employment associated with eco-innovation include information on waste, recovery and recycling (re-use), and for the first time, repairs, maintenance, and rental services.

Table 1 presents the results of the analysis of data based on Eco-IS for the years 2013-2017.

The results, which are based on Eco-IS data that refers to the period 2013-2017, indicate the existence of huge differences between the EU-15 group and the new members of the Union when it comes to comparing the overall situation in the field of eco-innovation.

At the head of the ranking of countries classified in the field of eco-innovation were Sweden, Finland, Germany, Luxembourg, Denmark, and Slovenia (only one representative of new member states), which obtained significantly higher relative results than the average for the EU 28. This group of countries is referred to as "Eco-Innovation Leaders."

Countries such as Austria, Italy, Spain, Portugal, the United Kingdom, France, Ireland, the Netherlands, and Malta are considered "Average Eco-Innovation Performers", whose synthetic index fluctuated around the average EU indicator.

The remaining countries are included in the group of "Catching up Eco-Innovation Performers."

Considering the value of the Eco-IS index, it should be noted that the countries located in the north and west of the Union are significantly ahead of countries located in the east and south east.

Clustering the data from the latest Innovation Union Scoreboard and from the Eco-Innovation Scoreboard, one can observe that there are three main groups of countries: those that have high scores in both sets of data (they are marked with a rhombus), those where both scores are medium (marked with a circle), and those where both scores are low (marked with a triangle) (see Chart 1 for more details). 
Table 1. Ranking of EU member states based on the Eco-Innovation Scoreboard, data for the period 2013-2017

\begin{tabular}{|c|c|c|c|c|c|}
\hline Country & 2017 & 2016 & 2015 & 2014 & 2013 \\
\hline Sweden & 144 & 128 & 121 & 121 & 140 \\
\hline Finland & 141 & 133 & 131 & 129 & 133 \\
\hline Germany & 139 & 135 & 132 & 135 & 138 \\
\hline Luxembourg & 139 & 140 & 125 & 139 & 114 \\
\hline Denmark & 120 & 129 & 131 & 131 & 129 \\
\hline Slovenia & 117 & 102 & 93 & 93 & 71 \\
\hline Austria & 113 & 109 & 105 & 103 & 107 \\
\hline Italy & 113 & 110 & 104 & 100 & 97 \\
\hline Spain & 112 & 99 & 109 & 111 & 120 \\
\hline Portugal & 105 & 96 & 92 & 92 & 81 \\
\hline United Kingdom & 105 & 113 & 113 & 104 & 130 \\
\hline Average for the EU & 100 & 100 & 100 & 100 & 100 \\
\hline France & 99 & 106 & 113 & 112 & 113 \\
\hline Ireland & 99 & 95 & 94 & 98 & 96 \\
\hline Netherlands & 88 & 92 & 100 & 99 & 96 \\
\hline Malta & 86 & 65 & 59 & 50 & 68 \\
\hline Belgium & 83 & 82 & 90 & 90 & 98 \\
\hline Czech Republic & 82 & 80 & 87 & 84 & 66 \\
\hline Lithuania & 82 & 82 & 66 & 66 & 63 \\
\hline Greece & 77 & 78 & 66 & 65 & 61 \\
\hline Slovakia & 74 & 79 & 61 & 61 & 42 \\
\hline Latvia & 73 & 86 & 65 & 65 & 43 \\
\hline Romania & 65 & 67 & 71 & 68 & 55 \\
\hline Hungary & 63 & 61 & 73 & 74 & 58 \\
\hline Estonia & 62 & 65 & 59 & 58 & 56 \\
\hline Poland & 59 & 56 & 44 & 53 & 30 \\
\hline Cyprus & 45 & 56 & 43 & 44 & 33 \\
\hline Bulgaria & 38 & 29 & 29 & 31 & 20 \\
\hline
\end{tabular}

Note: for the standardization of the indicator, the "Distance from reference data" method was used, taking into account the EU average, defined as a reference and a set of 100. A population-based weighting was assigned to the national data referring to the individual indicators in order to estimate the EU average, correcting deviations resulting from including the smallest EU countries in the calculations.

The table does not include data for Croatia as they were incomplete.

Source: own elaboration based on Eco-Innovation Scoreboard data 2013-2017.

Table 2. Detailed Eco-Innovation Scoreboard indicators for European Union Member States for 2017

\begin{tabular}{|l|c|c|c|r|r|}
\hline \multicolumn{1}{|c|}{ Country } & El inputs & El activity & El results & REP & SER \\
\hline Sweden & 166 & 148 & 182 & 154 & 77 \\
\hline Finland & 200 & 155 & 202 & 49 & 102 \\
\hline Germany & 178 & 151 & 130 & 121 & 113 \\
\hline Luxembourg & 104 & 124 & 220 & 183 & 72 \\
\hline
\end{tabular}




\begin{tabular}{|l|r|r|r|r|r|}
\hline \multicolumn{1}{|c|}{ Country } & El inputs & El activity & El results & REP & SER \\
\hline Denmark & 178 & 58 & 154 & 139 & 70 \\
\hline Slovenia & 141 & 124 & 153 & 66 & 130 \\
\hline Austria & 91 & 142 & 115 & 128 & 89 \\
\hline Italy & 66 & 111 & 112 & 180 & 101 \\
\hline Spain & 75 & 106 & 139 & 162 & 72 \\
\hline Portugal & 104 & 134 & 100 & 107 & 81 \\
\hline United Kingdom & 102 & 87 & 65 & 160 & 82 \\
\hline France & 118 & 10 & 107 & 110 & 89 \\
\hline Ireland & 113 & 58 & 69 & 174 & 55 \\
\hline Netherlands & 88 & 38 & 91 & 111 & 77 \\
\hline Malta & 23 & 116 & 77 & 163 & 7 \\
\hline Belgium & 94 & 11 & 93 & 95 & 75 \\
\hline Czech Republic & 81 & 126 & 49 & 44 & 111 \\
\hline Lithuania & 29 & 94 & 93 & 91 & 106 \\
\hline Greece & 57 & 96 & 142 & 50 & 63 \\
\hline Slovakia & 27 & 90 & 33 & 87 & 124 \\
\hline Latvia & 41 & 41 & 105 & 75 & 110 \\
\hline Romania & 53 & 37 & 55 & 60 & 113 \\
\hline Hungary & 39 & 47 & 13 & 76 & 125 \\
\hline Estonia & 50 & 76 & 90 & 2 & 109 \\
\hline Poland & 43 & 17 & 53 & 38 & 145 \\
\hline Cyprus & 4 & 39 & 113 & 62 & 6 \\
\hline Bulgaria & 30 & 37 & 33 & 4 & 92 \\
\hline
\end{tabular}

REP - Resource Efficiency performance; SER - Socio-Economic Results.

Source: own elaboration based on Eco-Innovation Observatory Thematic Report on Water (2018).

According to the data from the Eco-IS 2017 edition, Poland was in third place (before Cyprus and Bulgaria), achieving a result significantly lower than the EU average (59 vs 100) and a significantly lower result than the one obtained by Sweden (144 vs $100)$, an EU leader in eco-innovation. Poland is low in all indicators calculated in the Eco-IS, with a particularly low level in R\&D spending and investments in innovation (indicator 43), innovative activity (indicator 17), as well as the economic performance of the implemented Eco-IS innovation (index 53) (Details Table 2). It is worth emphasizing, however, that while the results from the "hard" components of the indicator are consistent with the ranking and the synthetic index, the results in the three groups of countries, taking into account the socio-economic results, are very diverse. In this case, Poland, Hungary, and Slovakia (145, 125 and 124, respectively) had better scores than many countries - even the Eco-Innovation Leaders. In terms of this variable, Poland was the best performing EU country, in particular, in the indicators for employment in the ecological and circular economy sectors, while Slovakia achieved the best results in terms of the revenue ratio in the ecological and circular economy sectors (as a percentage of total revenues in all companies). In this respect, Sweden, Luxembourg, and Denmark obtained results well below the EU average. 
In the context of these results, it should be underlined that the strategic goal of the sustainable growth of the Polish economy should refer to reducing the existing imbalance between economic and social growth, as well as between socio-economic development and the natural environment (Kasztelan 2010).

\section{The innovativeness and international competitiveness of enterprises - theoretical issues and results of empirical research}

The interdependence between innovation and international competitiveness is the subject of research in many countries. The international competitiveness of enterprises may be based on distinguishing the product offer (differentiation) or the cost advantage. The results of research conducted at the macro and meso level indicate that, in the long term, innovations that bring a competitive advantage resulting from differentiation bring better results than innovations resulting in a cost advantage (Verspagen \& Wakelin 1997; Fagerberg 2002; Montobbio 2003).

For the purposes of this study, we assume that the international competitiveness of an enterprise is its ability to achieve and maintain a competitive advantage on a foreign market, or on a domestic market surrounded by foreign competitors, resulting from the resources it owns. Due to the type of data used in the study, this measure will be the entity's declaration regarding sales on foreign markets (exports).

One of the main factors that build the international competitiveness of enterprises is product innovation. The differentiation of the offer has become a more important success factor for exporters in many industries than the cost advantage, while in cost competition it is increasingly important to maintain a competitive level of product quality (Calantone \& Knight 2000).

In research on British enterprises, it was found that innovation performance increases the likelihood of firms starting to export (Bleaney \& Wakelin 2002). In this vein, research on Spanish companies showed that the involvement of companies in the introduction of product innovations increases the probability of penetrating new markets (Cassiman \& Martinez-Ros 2007).

Becker and Egger (2007), in their study on German enterprises, proved that product innovation is the leading factor in strengthening the propensity to develop exports.

It has to be underlined that empirical studies rarely confirm such an unequivocal influence of process innovations on exports, as in the case of product innovations (Becker \& Egger 2007). Research of Norwegian, Swedish, and Finnish enterprises found a significant positive impact of product innovations on both the propensity to export and the intensity, while the impact of process innovations is insignificant in these companies (Clausen \& Pohjola 2009). 
While research on the relationship between SD/CSR and innovations and their impact on enterprises' results do not give clear conclusions (Marin 2014), many empirical studies conducted, mainly in mature economies, show a positive relationship between CSR and innovations in the context of companies' competitiveness (Surroca et al. 2010; Gonzalez-Ramos et al. 2014).

Some authors even say that eco-innovation is more important than "conventional" innovation in determining the company's performance (Doran \& Ryan 2012).

Companies that use the SD concept have to introduce various types of innovations (including product, process, marketing, and organizational innovations) with a positive environmental (and social) impact that can be a source of competitive advantage (Bansal 2005).

It should be emphasized that, in most cases, environmental innovations/eco-innovations have a typical business goal aimed at reducing the costs of the production process or product characteristics. Alternatively, they are designed to improve product quality and thus improve the competitive situation of the company while reducing the environmental impact. This type of eco-innovation is no different from other innovations regarding products or processes that are also aimed at increasing process efficiency or gaining market (Buczkowski et al. 2016).

Carillo-Hermosilla et al. (2009, p. 199) list the following E-I implications for a company's competitiveness: increasing the efficiency of raw materials and energy use; cost reduction; improving the functionality of products (better adaptation to the needs of buyers); creating new markets; increasing sales revenues; improving profitability.

Involvement in E-I is more likely when achieving a positive environmental impact can be combined with savings and improved efficiency (Horbach et al. 2013).

E-I can give an enterprise a cost competitive advantage thanks to the development of technology, new production processes, logistics, and innovative organizational solutions that mean that less use of materials and energy, and a reduction of emissions, production, and logistics, etc. (Gonzalez-Ramos et al. 2014).

Businesses that focus on cost-cutting innovations can also achieve environmental benefits through innovations in organic products, for example, by redesigning a product to reduce production costs (by reducing product functionality), which can also bring environmental benefits such as lower consumption of materials and energy, or lower emissions in production processes.

Although most E-I research focuses on building cost competitiveness, it should be noted that different types of E-I can also be a source of competitive advantage based on differentiation (McWilliams \& Siegel 2001; Bansal 2005). This type of advantage can be built by improving the product design and its functionality or by using product components that meet ecological standards, by increasing product durability, easy servicing, ecological recycling of the product and its packaging, etc.

In addition, the product/brand and/or offering differentiation can strengthen the company's reputation regarding the environment, which increases the value that stakeholders perceive and strengthens customer loyalty (Bhattacharya, Sen 2004). Building 
such a reputation may, however, require innovative marketing communication (like brand change/labeling, modified advertising, or PR), which will raise the awareness of SD/CSR sensitive customers (Boehe \& Cruz 2010).

A reputation based on sustainability increases the value perceived by customers and increases customer loyalty. Consumers, however, are inclined to prefer (and pay) for an eco-innovative product if it provides measurable, easy to estimate value-added (Doran \& Ryan 2012). Enterprises also introduce eco-innovations that serve only to reduce the impact on the environment. However, this is mainly the case when regulations interfere with the economy and somehow enforce innovations. On the other hand, some studies show that regulation is one of the most important factors that determine the transfer and diffusion of eco-innovation (Cetindamar 2001).

Many studies also describe the reverse relationship (reverse causality), that is, the coupling between export and innovation. The authors of the studies point to the learning process following sales to foreign markets (learning by exporting - LBE), which results in increased productivity, scale of sales, investments in R\&D, but also in new solutions in the products that are offered (Kafouros et al. 2008; Mińska-Struzik 2012). For example the research of Slovenian enterprises shows that past exportong increases the likehood (for medium and large companies) of introducting process innovation (Damijan, Kostevc, Polanec 2008). There is also a recent study (Hojnik, Ruzzier, Manolova 2018) exploring the relationship between internationalization and firm economic performance by investigating the mediating effect of eco-innovation. Based on data from 151 Slovenian internationalized companies with the SEM method, the authors discovered that internationalization is significantly and positively associated with the economic performance of the investigated enterprises, and that eco-innovation mediates this effect. The results show that introducing eco-innovation cannot be neglected when entering foreign markets.

Despite this positive relationship, the majority studies on the relationship between exports and innovations point to the lower effectiveness of "learning by exporting" and the stronger impact of innovation on exports (Monreal-Pérez, Aragón-Sánchez, Sánchez-Marín 2012).

For the purpose of this study, in order to examine the relationship between the introduction of eco-innovation and its presence with an innovative product on international markets, data from the Community Innovation Survey questionnaire are used.

In the CIS 2010-2012 questionnaire, a question regarding eco-innovation was added following the model of the 2006-2008 questionnaire. The questionnaire included an optional, one-page package of 15 questions about innovations that bring environmental benefits (eco-innovations), covering the types of eco-innovations potentially introduced by the surveyed companies, as well as questions about eco-innovation stimulators.

One of the questions from the eco-innovation block indicates the implementation of innovations with environmental benefits obtained by the end-user. At the same 
time, the questionnaire has a standard question regarding the market orientation of the enterprises. The question for enterprises whose largest market in terms of turnover was other EU, EFTA, and/or EU-candidate countries, was selected for the comparison.

Using data from both questions available for the entire and representative population of enterprises in EU countries, a graph showing the coexistence of two variables was constructed. Chart 2 illustrates this interdependence.

The results of the analysis are not completely unambiguous; however, they indicate that enterprises from countries with a higher overall Eco-IS index (higher than the EU average, i.e., Finland, Sweden, Germany, Slovenia, Luxembourg, Austria) are characterized by higher intensity of introducing eco-innovations that bring benefit to the final user and, at the same time, they are leaders of sales on foreign markets.

Enterprises from countries at the bottom of the Eco-IS ranking, including the countries of Central and Eastern Europe, are characterized by a relatively low intensity of introducing eco-innovations that bring benefits to the final user, and there is also a relatively low intensity of exports. The exceptions are enterprises from Slovenia and the Czech Republic. However, it should be emphasized that Slovenia has occupied a very high position in the Eco-IS ranking for many years, belonging to the Group of Eco-Innovation Leaders, while the Czech Republic, although its synthetic index is lower than the EU average, is the leader of the so-called eco-innovation catching-up countries.

\section{Conclusion}

In light of the Strategy for the European Union, eco-innovations will definitely play one of the most important roles in stimulating the development of the economies of the Member States. The proper implementation of the eco-innovation policy should, in this context, become one of the most important tasks for the Polish government (Grodzka \& Zygierewicz 2008).

The results of analysis, in particular, concerning the macro-level, indicate that the Polish economy has a long way to go in terms of the ecological solutions used, and the process itself is long-lasting and requires huge financial outlays.

It should be underlined, however, that the interrelation between the overall level of innovativeness and the overall level of eco-innovativeness was proven, although it does not indicate causality.

It seems that accelerating the implementation of eco-innovation should be accompanied by improving environmental standards, while the approach to increasing innovation should be left to industry, and not to standard-setting organizations. Environmental standards should promote continuous improvement and should leave as small a margin of uncertainty as possible at every stage of the eco-innovation implementation process (Porter \& van der Linde 1995a, 1995b). 
The Government's efforts should be directed not only to changing the current environmental policy, but also to building the basis for the creation of a legal and institutional environment to promote changes in education, the behavioral attitudes of citizens, and the objectives of the companies (Kassenberg 2011; Miedziński 2013). This concerns not only eco-innovation but also "conventional" innovation, due to its proven interrelation. This requires increased spending on innovation and, simultaneously, an increase in the awareness of enterprises regarding the benefits of introducing different types of innovation as well as eco-innovations for building their market position, measured in a more holistic and long term perspective.

An important difficulty in the case of eco-innovation is the fact that the return on $\mathrm{R} \& \mathrm{D}$ investments incurred for technologies related to the environment is lower than the social effects of expenditures incurred; hence, companies are not strongly determined to invest in this type of innovation.

Polish companies, which in many cases are focused on achieving the earliest possible profit, without taking into account the long-term development perspective, should recognize that investing both in conventional innovation and eco-innovation will bring benefits in the long run. These benefits will be in the form of achieving a competitive advantage in an area that would be impossible to achieve in a traditionally run economy and building an international competitive advantage (Klima 2017, 2018).

Based on Community Innovation Survey data, significant shortcomings regarding the international competitive advantage are shown in the results of the analysis of the export activities of European Union enterprises (including Poland) in terms of innovations aimed at environmental protection, with particular emphasis on the needs of the final buyer.

It looks like Polish enterprises are somehow "stuck in the middle" - they do not have a serious competitive advantage concerning product-related eco-innovation, and at the same time, there is no significant international sales intensity of these products.

There is long way to go before they can achieve a satisfactory level of international sales of innovation related to ecological issues. This is probably the result of the still low level of awareness of the role of eco-innovation in building a long-term international competitive advantage; on the other hand, it also results from significant financial constraints.

Eco-expenditres can be enhanced by public financial support. Thus the applications to EU progmrammes, like Horizon Europe, which promote projects aimed at eco-innovation, should significanlty increse (Ziółko \& Mróz 2015). 
Eco-innovation and International Competitiveness of Enterprises...

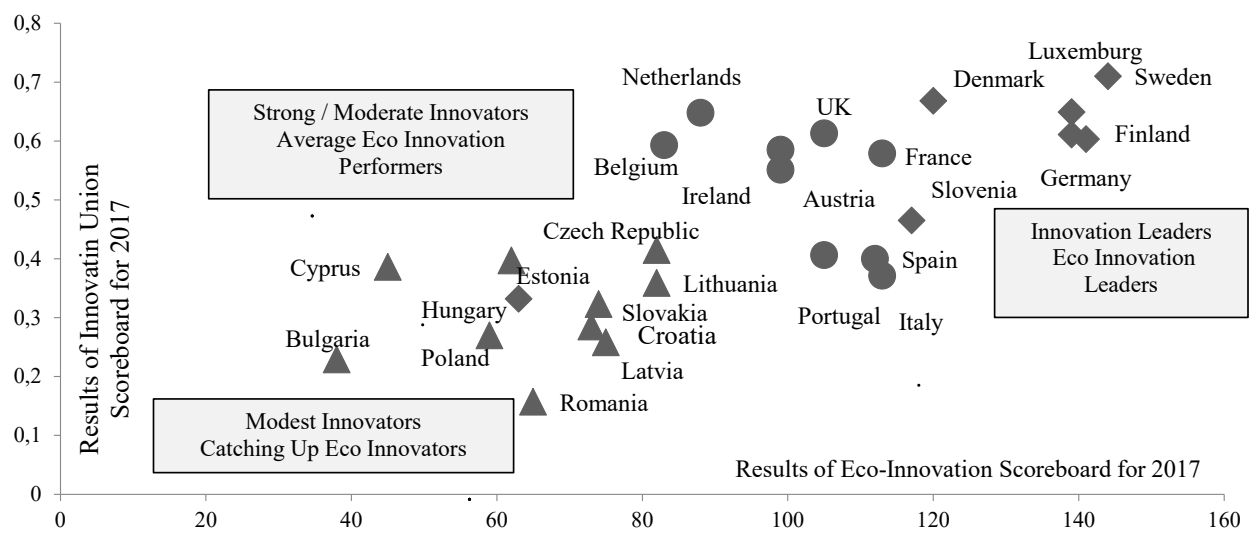

Chart 1. The interrelation between the level of overall innovativeness and the level of eco-innovation performance of the European Union member states, data for 2017

Source: own elaboration based on data from the Innovation Union Scoreboard 2017 and Eco-Innovation Scoreboard 2017.

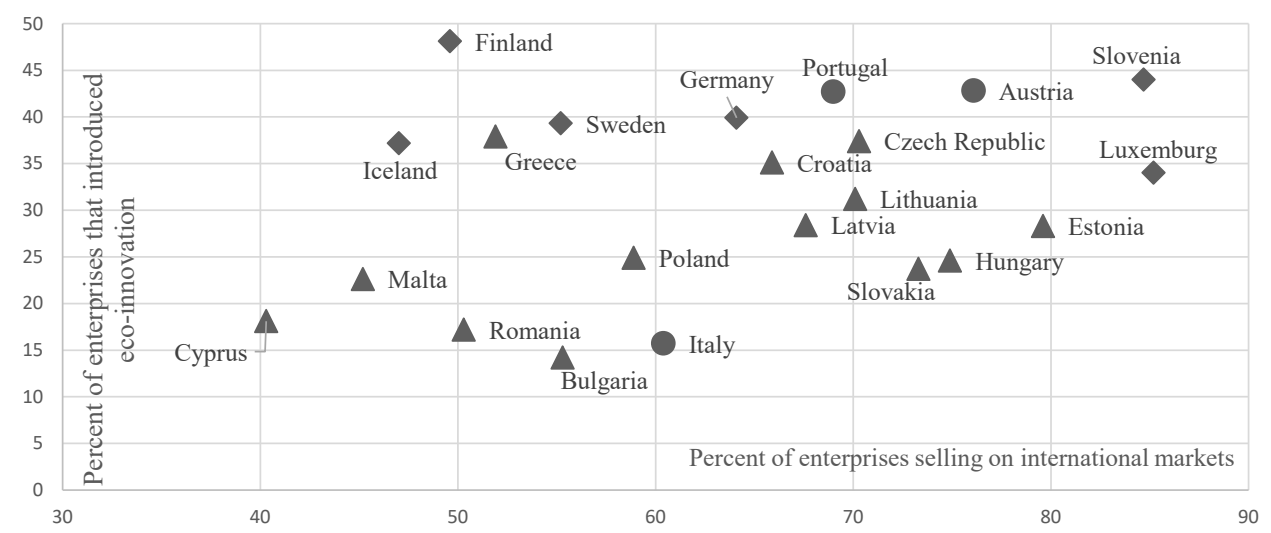

Chart 2. Coexistence of the introduction of eco-innovation with benefits for the end-user and sales on international markets

Source: own elaboration based on data from Eurostat Community Innovation Survey 2010-2012. http://epp.eurostat.ec.europa.eu/portal/page/portal/science_technology_innovation/data/database (accessed: 1.03.2019) 


\section{Acknowledgments}

The author is grateful to the participants of the conference organized by SGH KGS in Warsaw 9-10.05.2019, "KGŚ World Economy 2019. Learning from the Past and Designing the Future" for their great and insightful comments. During this event, the preliminary version of this research was presented in the form of a poster.

The research was supported with funds from the Polish Ministry of Science and Higher Education granted to Collegium of World Economy (KGŚ), SGH - Warsaw School of Economics "International competitiveness of enterprises” KGS/S18/14/2018.

\section{References}

Arundel, A., Kemp, R. (2009), Measuring Eco-Innovation, UNI-MERIT Research Memorandum. pp. 2009-2017.

Bansal, P. (2005), Evolving Sustainably: A Longitudinal Study of Corporate Sustainable Development, Strategic Management Journal, Vol. 26 (1). https://doi.org/10.1002/ smj.441

Becker, S., Egger, P. (2007), Endogenous product vs. process innovation and firm's propensity to export, Empirical Economics.

Bhattacharya, C., Sen, S. (2004), Doing better at doing good: When, why, and how consumers respond to corporate social initiatives, "California Management Review", Vol. 47 (1)1, pp. 9-24. https://doi.org/10.2307/41166284

Bleaney, M., Wakelin, K., (2002), Efficiency, innovation and exports, "Oxford Bulletin of Economics and Statistics”, No. 1. https://doi.org/10.1111/1468-0084.00001

Boehe, D.M., Cruz, L.B., (2010), Corporate Social Responsibility, Product Differentiation Strategy and Export Performance, "Journal of Business Ethics", Vol. 91 (3). https:// doi.org/10.1037/t35909-000

Brusoni, S., Cefis, E., Orsenigo, L., (2006), Innovate or die? A critical review of the literature on innovation and performance, Working Paper No. 179, CESPRI, Università Commerciale Luigi Bocconi, Milano.

Buczkowski, B., Dorożyński, T., Kuna-Marszałek, A., Serwach, T., Wieloch, J. (2016), Społeczna odpowiedzialność businessu. Studia przypadków firm międzynarodowych, Łódź, Wydawnictwo Uniwersytetu Łódzkiego. https://doi.org/10.18778/8088-1099.01

Calantone, R., Knight, G., (2000), Role of Product Quality in International Performance of Industrial Firms, "Industrial Marketing Management", No. 6. https://doi. org/10.1016/S0019-8501 (00)00124-3

Carrillo-Hermosilla, J., del Río, P., Könnölä, T., (2009), Eco-innovation: When Sustainability and Competitiveness Shake Hands, Palgrave Macmillan: Hampshire. https:// doi.org/10.1057/9780230244856

Cassiman, B., Martinez-Ros, E., (2007), Product innovation and exports. Evidence from Spanish manufacturing, Working Paper, IESE Business School. 
Clausen, T.H., Pohjola, M., (2009), International competitiveness. Internal capabilities and open innovation as sources of export performance, Working Paper No. 05/09, MICRO-DYN, EU $6^{\text {th }}$ Framework Programme.

Community Innovation Survey 2010-2012, http://epp.eurostat.ec.europa.eu (accessed: 1.03.2019)

Damijan, J.P., Kostevc, C., Polanec, S. (2008), From innovation to exporting or vice versa? Causal link between innovation activity and exporting in Slovenian microdata, Working Paper No. 05/08, MICRO-DYN, EU $6^{\text {th }}$ Framework Programme.

De Marchi, W. (2012), Environmental innovation and R\&D cooperation: Empirical evidence from Spanish manufacturing firms, "Research Policy", Vol. 41, pp. 614-624. https://doi.org/10.1016/j.respol.2011.10.002

Doran, J. (2012), Are differing forms of innovation complements or substitutes?, European Journal of Innovation Management, Vol. 5 (3), pp. 351-371. https://doi. org/10.1108/14601061211243675

Doran, J., Ryan, G., (2012), Regulation and firm perception, eco-innovation and firm performance, European Journal of Innovation Management, Vol. 15 (4), pp. 421-441. https://doi.org/10.1108/14601061211272367

Dorożyński, T., Kuna-Marszałek, A. (2016), Business and the environment, Łódź, Wydawnictwo Uniwersytetu Łódzkiego.

EIO (Eco-Innovation Observatory) (2010), Methodological Report. Eco-Innovation Observatory. Funded by the European Commission, DG Environment, Brussels.

EC (European Commission) (2010), Europe 2020 - A European strategy for smart, sustainable and inclusive growth, http://ec.europa.eu/europe2020 (accessed: 1.03.2019).

Fagerberg, J. (2002), Technology, growth and competitiveness, Edward Elgar, Cheltenham.

Gerlach, A., (2003), Sustainable entrepreneurship and innovation, Center for Sustainability Management, University of Lüneburg, [in:] Proceedings from the 2003 Conference on Corporate Social Responsibility and Environmental Management, Leeds, UK.

González-Ramos, M.I., Donate, M.J., Guadamillas, F. (2014), Technological Posture and Corporate Social Responsibility: Effects on Innovation Performance, Environmental Engineering and Management Journal, Vol. 13 (10). https://doi.org/10.30638/ eemj.2014.279

Hall, J., Vredenburg, H. (2003), The challenges of innovating for sustainable development, "MIT Sloan Management Review", Vol. 45, No. 1, pp. 61-69.

Halpern, L. (2007), Literature survey on the links between innovation, competition, competitiveness, entry \& exit, firm survival and growth, Working Paper No. 02/07, MICRO-DYN, EU $6^{\text {th }}$ Framework Programme.

Hashi, I., Stojcic, N. (2010), The impact of innovation activities on firm performance using a multi-stage model. Evidence from the Community Innovation Survey 4, Working Paper No. 17/10, MICRO-DYN, EU $6^{\text {th }}$ Framework Programme. https://doi. org/10.2139/ssrn.1680935

Hojnik, J., Ruzzier, M., Manolova, T.S. (2018), Internationalization and economic performance: The mediating role of eco-innovation, "Journal of Cleaner Production", Vol. 171, pp. 1312-1323. https://doi.org/10.1016/j.jclepro.2017.10.111 
Horbach, J. (2008), Determinants of environmental innovation - new evidence from German panel data sources, "Research Policy", Vol. 37, No. 1, pp. 163-73. https:// doi.org/10.1016/j.respol.2007.08.006

Horbach, J., Oltra, V., Belin, J. (2013), Determinants and Specificities of Eco-Innovations Compared to Other Innovations - An Econometric Analysis for the French and German Industry Based on the Community Innovation Survey, Industry and Innovation, Vol. 20 (6), pp. 523-543. https://doi.org/10.1080/13662716.2013.833375

Kafouros, M.I., Buckley, J.P., Sharp, J.A., Wang, C. (2008), The role of internationalization in explaining innovation performance, Technovation, No. 28 (1/2).

Kassenberg, A. (2011), EIO country brief 2010: Poland, Eco-Innovation Observatory.

Kasztelan, A. (2010), Środowiskowa konkurencyjność regionów - próba konceptualizacji, "Problemy Ekorozwoju”, Vol. 5, No. 2, pp. 77-86.

Kemp, R. (2000), Technology and environmental policy: innovation effects of past policies and suggestions for improvement, paper for OECD workshop on Innovation and Environment, 19 June 2000, Paris.

KIS (Krajowa Inteligentna Specjalizacja), (2014), Ministerstwo Gospodarki, Annex 4 to the Enterprise Development Programme (Program Rozwoju Przedsiębiorstw) adopted by the Council of Ministers on 8 April 2014, http://www.mg.gov.pl/Wspieranie+przedsiebiorczosci/Polityki+przedsiebiorczosci+i+innowacyjnosci/Krajowe+inteligentne+specjalizacje (accessed: 8.03.2019).

Klima, S. (2017), Rola rozwoju zrównoważonego w kształtowaniu konkurencyjności przedsiębiorstw [in:] M. Maciejewski, W. Wach (eds.), Handel zagraniczny i biznes międzynarodowy we wspótczesnej gospodarce, Uniwersytet Ekonomiczny w Krakowie, Kraków, pp. 215-226.

Klima, S. (2018), Ekoinnowacje i ich wpływ na konkurencyjność przedsiębiorstw, "Przedsiębiorczość i Zarządzanie", Vol. 19, z. 10, cz. 3, pp. 57-69.

Lewandowska, M.S. (2015), Eco-innovation driving forces: results from Community Innovation Survey, [in:] Innovation and Poland's performance in 2007-2014, M. Weresa (ed.), (Competitiveness Report: Poland), Warsaw, OW SGH, pp. 307-328.

Lewandowska, M.S. (2016), Do government policies foster environmental performance of enterprises from CEE region?, "Comparative Economic Research", Vol. 19, No. 3 , pp. 45-67. https://doi.org/10.1515/cer-2016-0020

Lewandowska, M.S. (2018), Koncepcja otwartych innowacji. Perspektywa polskich przedsiębiorstw przemysłowych, Warszawa, Oficyna Wydawnicza SGH.

Marin, G. (2014), Do eco-innovations harm productivity growth through crowding out? Results of an extended CDM model for Italy, Research Policy Vol. 43, pp. 301-317. https://doi.org/10.1016/j.respol.2013.10.015

McWilliams, A., Siegel, D.S. (2001), Corporate Social Responsibility: A Theory of the Firm Perspective, Academy of Management Review, Vol. 26 (1).

Miedziński, M., Country Profile 2013: Poland, Eco-Innovation Observatory.

Mińska-Struzik, E. (2012), Learning by exporting as a source of innovation in Asian companies, Research Papers of Wroclaw University of Economics (Prace Uniwersytetu Ekonomicznego we Wrocławiu), Issue 256.

Monreal-Pérez, J., Aragón-Sánchez, A., Sánchez-Marín, G. (2012), A longitudinal stu$d y$ of the relationship between export activity and innovation in the Spanish firm. 
The moderating role of the productivity, International Business Review, No. 21 (5). https://doi.org/10.1016/j.ibusrev,2011.09.010

Montobbio, F. (2003), Sectoral patterns of technological activity and export market share dynamics, "Cambridge Journal of Economics", Vol. 27. https://doi.org/10.1093/ cje/27.4.523

MŚ (Ministerstwo Środowiska) (2008), Polityka ekologiczna państwa w latach 2009-2012 z perspektywa do roku 2016, Warszawa.

OECD (2009), Eco-Innovation in Industry: Enabling Green Growth, OECD Publishing, Paris.

(Oslo Manual) Podręcznik Oslo (2005), Pomiar działalności naukowej i technicznej: proponowane zasady gromadzenia i interpretacji danych dotyczacych innowacji technologicznych, wyd. 3, Organisation for Economic Co-operation and Development - Statistical Office of the European Communities, Warszawa.

Pavitt, K. (1984), Sectoral patterns of technical change: Towards a taxonomy and a theory, "Research Policy", No. 13, pp. 343-373. https://doi.org/10.1016/00487333(84)90018-0

Porter, M. (1991), America's Green Strategy, "Scientific American”, Vol. 264, No. 4, p. 168. https://doi.org/10.1038/scientificamerican0491-168

Porter, M.E., van der Linde, C. (1995a), Towards a new conception of the environment-competitiveness relationship, "Journal of Economic Perspective", Vol. 9 (4), pp. 97-118. https://doi.org/10.1257/jep.9.4.97

Porter, M.E., van der Linde, C. (1995b), Green and Competitive. Ending the Stalemate, "Harvard Business Review", September-October 1995, pp. 120-134.

Rennings, K. (2000), Redefining innovation - eco-innovation research and the contribution from ecological economics, "Ecological Economics", Vol. 32, No. 2, pp. 319-332. https://doi.org/10.1016/S0921-8009(99)00112-3

Stojcic, N., Hashi, I., Telhaj, S. (2011), Innovation activities and competitiveness. Empirical evidence on behaviour of firms in new EU member states and candidate countries, CASE Network Studies and Analyses, No. 424, Warsaw. https://doi.org/10.2139/ ssrn. 1825882

Surroca, J., Tribó, J.A., Waddock, S. (2010), Corporate Responsibility and Financial Performance: The Role of Intangible Resources, "Strategic Management Journal", Vol. 31 (5). https://doi.org/10.1002/smj.820

Verspagen, B., Wakelin, K. (1997), International competitiveness and its determinants, "International Review of Applied Economics", Vol. 11, No. 2. https://doi. org/10.1080/02692179700000012

Węgrzyn, G. (2013), Ekoinnowacje w Polsce na tle krajów unii europejskiej, „Ekonomia i Środowisko", Vol. 3 (46), pp. 138-148.

Wizja zrównoważonego rozwoju dla polskiego biznesu 2050, Ministerstwo Gospodarki, Price Waterhouse Coopers, http://www.pwc.pl/pl_PL/pl/publikacje/raport_wizja_ zrownowazonego_rozwoju_dla_polskiego_biznesu_2050.pdf (accessed: 8.03.2019).

Wysokińska, Z. (2013), Transition To A Green Economy In The Context Of Selected European And Global Requirements For Sustainable Development, "Comparative Economic Research. Central and Eastern Europe”, Vol. 16 (4), pp. 205-228. https:// doi.org/10.2478/cer-2013-0034 
Wysokińska, Z. (2014), Response of the EU Member States to Climate Change in the Context of EU Policy and Strategy, "Comparative Economic Research". Vol. 17 (3), pp. 85-99. https://doi.org/10.2478/cer-2014-0024

Wysokińska, Z., Witkowska, J. (2016), Zrównoważony rozwój. Wybrane aspekty makro- $i$ mikroekonomiczne, Łódź, Wydawnictwo Uniwersytetu Łódzkiego.

Yarahmadi, M., Higgins, P.G. (2012), Motivations towards environmental innovation. A conceptual framework for multiparty cooperation, "European Journal of Innovation Management”, Vol. 15, No. 4, pp. 400-420. https:/doi. org/10.1108/14601061211272358

Ziółko, M., Mróz, J. (2015), Wpływ ekoinnowacji na wzrost konkurencyjności przedsiębiorstw, “Acta Universitatis Nicolai Copernici”, Zarządzanie XLII - No. 1. https:// doi.org/10.12775/AUNC_ZARZ.2015.006

\section{Streszczenie}

\section{Eko-innowacje a międzynarodowa konkurencyjność przedsiębiorstw. Wyniki dla państw członkowskich Unii Europejskiej}

Intensywne globalne ocieplenie, kurczące się zasoby naturalne, zanieczyszczenie środowiska to czynniki wpływające na intensywność debaty na temat tego, co tworzy „zdrową gospodarkę". Biorąc powyższe pod uwagę, celem niniejszego artykułu jest przedstawienie przeglądu wyników w zakresie eko-innowacji dla państw - członków Unii Europejskiej, w kontekście ich ogólnego poziomu innowacyjności. Artykuł dostarcza również wiedzy na temat roli innowacji ekologicznych jako siły napędowej międzynarodowej konkurencyjności przedsiębiorstw z krajów Unii Europejskiej. Wyniki analizy makro pokazują, że istnieje współzależność między poziomem innowacyjności a poziomem wdrażania eko-innowacji w państwach członkowskich UE. Z kolei analiza na poziomie mikro przeprowadzona dla przedsiębiorstw UE pokazuje, że istnieje współzależność między intensywnością wprowadzania eko-innowacji przynoszących korzyści użytkownikom końcowym a poziomem międzynarodowej konkurencyjności przedsiębiorstw mierzonym intensywnością eksportu. Przedsiębiorstwa z krajów o wyższym ogólnym wskaźniku IUS i Eco-IS charakteryzują się wyższą intensywnością wdrażania eko-innowacji, przy jednoczesnej intensywnej obecności na rynkach zagranicznych. Przedsiębiorstwa z krajów o niskim IUS, i niskim rankingu Eco-IS, w tym kraje Europy Środkowej i Wschodniej, charakteryzują się z kolei stosunkowo niską intensywnością wprowadzania eko-innowacji przy niskiej intensywności eksportu.

Słowa kluczowe: Eko-innowacje, międzynarodowa konkurencyjność, Innovation Union Scoreboard, Eco-innovation Scoreboard, Community Innovation Survey 